\title{
How Far Does The Indonesian Constitutional Court Decision on Societal Organization Law Strengthen Democracy?
}

\author{
Andy Omara and Kristina Viri
}

Universitas Gadjah Mada

*Corresponding author: Andy Omara. Email: andy.omara@mail.ugm.ac.id

\begin{abstract}
Freedom of association and assembly is one of the fundamental human rights that should be protected in the democratization process. The guarantee of this right is based on the conceptual argument that there is an interrelation between law, human rights and democracy. Protecting freedom of association and assembly is both legal and constitutional responsibility. It also serves as an indicator of working democracy. This constitutional value is further supported by the Constitutional Court Decision 82/PUU-XI/2013 (about Societal Organization Law) which declares registration for societal organization (Ormas Law) is optional. This paper analyses the implications of the Constitutional Court Decision about Societal Organization Law using a conceptual and legislation approach. This paper concludes: 1) The guarantee of the rights of association and assembly in the Constitutional Court Decision about Societal Organization Law provides strict limits for the state so as not to violate the rights of association and assembly; 2) The implication of the decision of the Constitutional Court is that various regulations that contradict this decision have no binding legal force. However, to see the validity of the conflict, it is necessary to conduct a judicial review. This constitutional court decision is strengthen democratization process in Indonesia. Because it guarantees the right to association so that it will open a wider civic space.
\end{abstract}

Keywords: freedom of association in Indonesia, constitutional court decision, democratization in Indonesia.

\section{INTRODUCTION}

\subsection{Background}

Indonesia is a country which based on rule of law. It confirmed in the Article 1 paragraph 3 of Indonesian Constitution 1945. According to Dicey one of characteristic of rule of law is the existence of constitution which based on human right.[1] Furthermore, Jimly Asshiddiqie argues that the rule of law must be democratic, and a democratic state must be based on law. [2]

Since 1998, democratization has taken place in Indonesia. It was marked by opening-up of political space, opening-up of civic space, and freeing of the media. There was a positive spirit demanding greater accountability from government have all emerged.[3] Civil society is one of the key actor in the democratization process.[4] To open the space for civil society participation, it is necessary to guarantee the rights of association and assembly. The rights of association and assembly are also human rights that must be guaranteed in a democratic state based on rule of law. With this guarantee the people can organize their self to form organizations and participate in the development.[5]

Freedom of association and assembly in Indonesia is guaranteed under the Article 28 and Article 28 E paragraph 3 of the Indonesian Constitution 1945. This guarantee is confirmed in the Constitutional Court Decision Number 82/PUU-XI/2013 on Societal Organization Law. The judges revoke some articles that hinder the freedom of association and assembly. Some articles are regarding the mandatory registration and empowerment of Societal Organization (CSOs) by the government. Since this decision, the registration of CSOs has become voluntary and the government cannot empower CSOs to enforce their will.

In practice, however, some regions through their local regulations still require registration for all types of 
societal organizations.[6] Some of regions also have local regulation about CSO's empowerment.[7] These regulations are contradict with the Constitutional Court Decision number 82/PUU-XI/2013.

\subsection{Research Questions}

So that this paper aims to answer two important questions:

1) How does constitutional court decision on Societal Organization Law guarantee right to association and assembly in Indonesia?

2) How does the implication of constitutional court decision on Societal Organization Law to the freedom of association and democratization in Indonesia?

\subsection{Research Method}

This research is using normative legal method. Soekanto defines normative legal research method as method conducted by examining library materials. [8] Normative legal research includes several studies, one of them is research on the level of vertical synchronization of laws and regulations. This study aims to test the level of synchronization between Constitutional Court Decision about Societal Organization Law and the regulations that implement it. The data that has been collected is analysed using qualitative analysis with a conceptual and statutory approach

\section{THE GUARANTEE OF RIGHT TO ASSOCIATION AND ASEMBLY IN THE CONSTITUTIONAL COURT DECISION ABOUT SOCIETAL ORGANIZATION LAW}

The Constitutional Court Decision Number on Societal Organization Law has avoid several articles that violate the rights of association and assembly. In this decision the Constitutional Court interprets Article 28 and Article 28 E paragraph 3 of the 1945 Constitution. It can be describe as follow:

\subsection{Guarantee of Right to Associate and Assembly for Citizens}

In the consideration number [3.17] the court interpreted the rights of association and assembly for citizens as follows:[9]

a) Everyone has right to form or participate in membership or to become administrators of organizations in social life within the territory of the Republic of Indonesia.

b) Guarantees of human rights are not based on the individual right. Human rights must be placed in relation to the obligations to society and the state, especially the values adopted by the Indonesian nation. The Law on Societal Organization is a manifestation of the obligations that the community fulfils.

c) The community/organization can regulate their self as long as it does not conflict with the 1945 Constitution and regulation.

This consideration is strengthen right to associate for Citizen. In point a) mention that everyone has right to form or participate in organization within the territory of republic Indonesia. There is no condition which must be met to be able to form or participate in Organization. This provision also confirms the abolition of the registration to establish the organization.

Regarding the provisions on registration for CSOs that are not legal entities, the Court interprets that registration is not mandatory. In consideration of number [3.19.4] the Court affirms that: [10]

a) The main principle for CSOs that are not legal entities: They can register themselves to government official and can also not register themselves.

b) When an CSOs that is not a legal entity has registered, its existence must be recognized as an CSOs that can carry out organizational activities within the regional and national scope.

c) CSOs that do not register to the authorized government agencies, they do not receive services from the government (state), but the state cannot designate such CSOs as prohibit CSOs.

Regarding empowerment under consideration number [3.19.7] CSOs are not obliged to participate in empowerment programs which organized by the state. Empowerment programs actually reduce the independence of CSOs. [11]

\subsection{Restriction for State}

In consideration of [3.17] and [3.18] the Court interpreted the right of association and assembly and its restriction for the state. It describe as follows:[12]

a) The legislators who represent the state in drafting laws must also not be arbitrary. Moreover, the law that was drafted regulates the existence and freedom of citizens which guaranteed in the constitution.

b) The state must not interfere too much with these rights and freedoms, except within the limits permitted by the constitution. The state must also provide space for the people to regulate themselves, as long as they do not conflict with the 1945 Constitution and the laws and regulations made by the state.

c) The state is allowed to make restrictions on this right as long as the restrictions are not excessive and are still within the framework of the sole purpose of respecting the rights and freedoms of others and to fulfil jus 
demands in accordance with considerations of morals, religious values, security and public order.

Regarding the registration of Societal Organization (CSOs), the Court provides limitations for the state [3.19.4]: If an CSOs does not register itself, the state may not designate an CSOs as a prohibited CSOs or the state cannot prohibit the activities of the CSOs as long as it does not carry out activities that disturb security, public order, or commit a violation of law. Meanwhile, regarding the empowerment of CSOs, the judge's consideration of point [3.19.7] states that the state may empower CSOs, but must not impose its will in an empowerment forum.

This interpretation strengthens the guarantee of the right to freedom of association and assembly for CSOs in the 1945 Constitution. With this consideration, the judge provides strict limitation for the state so as not to violate the rights of association and assembly.

\section{THE IMPLICATION OF}

CONSTITUTIONAL COURT DECISION
ABOUT SOCIETAL ORGANIZATION LAW TO THE FREEDOM OF ASSOCIATION AND

\section{DEMOCRATIZATION IN INDONESIA}

The 2013 Court Decision on Societal Organization Law invalidated some of articles of the Law. There are some implications related to implementation Law Number 17/2013 on Societal Organization one of them is about registration of societal organizations has become voluntary.

However, there are some regulations which obligate CSO's to register their self to government official. There are:[12]

\section{1) Bogor City, West Java}

Bogor Mayor Regulation Number 24/2016 (in the article 2 paragraph 1) states that every Societal Organizations/Institution must register its existence with the Regional Government. Because it states that registration is mandatory, so does the practice. All organizations are required to register themselves. The existence of this regulation is due to the mandate of the Regulation of the Minister of Home Affairs (Permendagri) No. 33 of 2012. The purpose of the establishment of this regulation is to control mass organizations in the city of Bogor.[13]

\section{2) Salatiga City, Central Java}

The regulations in Salatiga City do not include mandatory registration. This regulation appoints a team in charge of supervising and coaching CSOs. However, in the implementation, the existence of this regulation requires organizations to register at KESBANGPOL. One of the foundations in this city cannot carry out public campaign activities because it does not register with KESBANGPOL, even though this organization is already registered as a legal entity of the Foundation (Already registered with the Ministry of Law and Human Rights).[14] The government is aim to record and control all societal organization organizations in Salatiga City.[15]

\section{3) Surabaya City, East Java}

In Surabaya, there are two regulations regarding the registration of societal organizations. Based on these two regulations, registration of community organizations is mandatory. One community organization in Surabaya considers that registration at KESBANGPOL will complicate the organization that supervises government work. The government can revoke the permits of CSOs that are critical of government policies [16].

All regulations mentioned above are contradicting with constitutional court decision number 82/PUU$\mathrm{XI} / 2013$. To analyse this conflict, we will use Hans Kelsen's stufenbau theory.[17] Law and norm are organized in the hierarchy. Hans Nawiasky developed Hans Kelsen's theory with a theory called theorie van stufenbau der rechtsordnung. The grouping of norms according to the theory is as follow [18]:

Group 1: State fundamental norms

(Staatsfundamentalnorm);

Group 2: Basic Rules of the State (Staatsgrundgesetz);

Group 3: Formal legislation (Formellgesetz);

Group 4: Implementing regulations and autonomous regulations (verordnung en autonome)

The above-mentioned legislative system will be utilized to test whether the local regulations is constitutionally and legally valid. In addition, it is also important to locate the position of Court Decision. Where is the position of the Constitutional Court Decision in that hierarchy? The hierarchy of legislation does not say anything about the Court Decision. However, Looking at the group of norms presented by Nawiasky, the Constitutional Court's decision is included in the wet in materiele zin group, namely in group 3 . This is because the decision of the Constitutional Court is binding on the general public. Furthermore, based on Article 10 of Law Number 12 of 2011 concerning the Formation of Legislation, it is stated that the contents that must be regulated by law are: a. Further regulation regarding the provisions of the 1945 Constitution of the Republic of Indonesia; b. Order of a Law to be regulated by Law; c. ratification of certain international agreements; $d$. followup on the Constitutional Court's Decision; and/or e. meeting the legal needs of the community.

The Court decisions specifically the 2013 Court decisions invalidated some provision of the Laws. It means those provisions were not valid anymore because of the Court decisions. The Court decision becomes valid interpretation replacing the invalidated provisions.

In addition, the inclusion of the Court decision in the State Gazette indicates that the Court rulings equal to the law. The fact that the local regulations are inconsistent with the Court Decision can be the legal basis to 
invalidate the regional regulations. Such invalidation however should be based on the review conducted by the judiciary. It is therefore crucial to submit the petition to the Supreme Court asking to tests the legality of the local government. If the Court proved that it is not in line with the Court decisions it is likely that such provisions will be declared as invalid.

Regarding the democratization process, it is important to ensure opportunity of access and participation of Civil Society in decision-making processes. [19] A strong civil society is a one indicator for a strong democracy. [20] The constitutional court decision 2013 strengthens right to associate and assembly. It will influence societal organization in Indonesia because there will open wider civic space in Indonesia.

\section{CONCLUSION}

This paper concludes: 1) The guarantee of the rights of association and assembly in the Constitutional Court Decision on Societal Organization Law provides strict limits for the state so as not to violate the rights of association and assembly; 2) The implication of the decision of the Constitutional Court is that various regulations that contradict this decision have no binding legal force. However, to see the validity of the conflict, it is necessary to conduct a judicial review. This constitutional court decision is strengthen democratization process in Indonesia. Because it guarantees the right to association so that it will open a wider civic space.

\section{AUTHORS' CONTRIBUTIONS}

Andy Omara and Kristina Viri contributed to the design, implementation, and analysis of the research and to the writing of the manuscript.

\section{REFERENCES}

[1] Teguh Prasetyo, "Rule of Law dalam Dimensi Negara Hukum Indonesia”, Jurnal Ilmu Hukum Refleksi Hukum, Edisi Oktober 2010, pp. 133

[2] Sarja, Negara Hukum Teori dan Praktek, Thafa Media, 2016, pp. 33

[3] IDEA team, Democratization in Indonesia An Assessment, International Institute for Democracy and Electoral Assistance, 2000, pp. vii

[4] Ibid

[5] Pradjoto, Kebebasan Berserikat di Indonesia, Sinar Harapan, 1983, pp. 13-14

[6] Riza Imaduddin Abdali, Ronal Rofinadri, Miftah Fadli, Kristina Viri, Penyusunan Instrumen Alternatif Surat Keterangan Terdaftar, YAPPIKA, 2018. p. 20

[7] Ibid
[8] Soerjono Soekanto et all, Penelitian Hukum Normatif, Raja Grafindo Persada, 2014, p. 13

[9] Constitutional Court Decision Number 82/PUU$\mathrm{XI} / 2013$

[10] Ibid

[11] Ibid

[12] Ibid

[13] Riza Immadudin Abdali et all, Op.Cit, pp. 3-4

[14] Ibid; p. 3-4

[15] Ibid

[16] Ibid; pp. 53-54

[17] Sarja, Op.Cit, p. 33.

[18] Kristina Viri, Implikasi Pengujian Konstitusional Undang Undang Nomor 17 Tahun 2013 tentang Organisasi Kemasyarakatan terhadap jaminan hak berserikat dan berkumpul, Tesis Magister Hukum UGM, 2021, p. 142

[19] IDEA Team, Op.Cit, pp. 5

[20] Ibid 